\title{
POSSIBILITIES AND LIMITATIONS OF RESEARCH METHODS OF THE SOCIAL STRUCTURE IN THE ROMAN IRON AGE IN POLAND
}

\author{
MOŻLIWOŚCI I OGRANICZENIA METOD BADANIA \\ STRUKTURY SPOŁECZNEJ Z OKRESU \\ WPŁYWÓW RZYMSKICH NA ZIEMIACH POLSKICH
}

\author{
Natalia Gryzińska-Sawicka \\ Instytut Prahistorii, Uniwersytet im. Adama Mickiewicza \\ ul. Umultowska 89D, 61-614 Poznań, Poland \\ nataliagryzinska@gmail.com
}

\begin{abstract}
The question of structure of prehistoric communities constitutes an interesting, yet challenging research problem. Most often it is analyzed from the perspective of the equipment of individuals buried it cemeteries. Researchers dealing with the Roman period, largely base their studies on the qualitative and quantitative diversity of funerary material, assume that the richly furnished graves belonged to rich people (elites), and poorly equipped - respectively - to the poor. They take into account the present value of materials of which objects were made (gold, silver), even though they may not have been as significant as they are today. A major problem in the study of social structure turns out to be the poorly preserved bone material which often prevents anthropologists from determining sex and age of the deceased. The solution could be found in the study of fossil DNA, able to answer questions about the possible existence of kinship and family sectors in the cemeteries. What is more, the study of stable isotopes of oxygen, nitrogen and carbon, although not without limitations, can support archeology in finding answers to questions if diet could be related to social status (or dependent on sex, age, wealth, etc.). Finally, in the study of social structure, the research on divisions arising from labor and its distribution according to sex is also used. In the studies of social structure it is crucial to realize that burial is an intentional action, which is influenced by the aspirations of family members of the deceased, grief, emotions related to death, and even current "fashion". Therefore, asking questions about the social structure and using methods which are to help obtain the answers, what we really ask about is the attitude of the living towards the deceased and death itself, as well as their own idea of the afterlife.
\end{abstract}

KEY WORDS: Roman era, Wielbark culture, social structure.

The question of the structure of prehistoric societies has long been an interesting, yet challenging research problem for archeologists. Most frequently the attempts to discuss this phenomenon are based on the equipment of individuals buried 
in cemeteries of a particular culture (Siewiaryn 2011, p. 7), the study of settlements is, however, very seldom included in the research. At this point, the works of Kazimierz Godłowski (1960), Alina Kietlińska (1960, 1963) and Krystyna Czarnecka (1990) on the pre-Roman period and the period of Roman influence in Poland should me mentioned - these works relate primarily to the Przeworsk culture. Still, however, no research has been conducted on the social structure of population of the Wielbark culture. Attempts to determine the social structure, however, occupy lesser chapters in various general works on the prehistoric era or the Roman period in Poland. In studies of this type it can be observed that the issue of social structure is discussed through repeated patterns, often applied to different periods of prehistory, most often with a focus on class differences, supposedly indicated by the equipment of graves (Gryzińska-Sawicka 2014, p. 51). It is far too often uncritically assumed that on the basis of differences in the equipment of individual graves it is possible to draw conclusions on property and social stratification of a given society. In this way, cemeteries - if examined to determine the social structure, are described from the perspective of the equipment as a symbol of the power of people buried there. This coincides with the conclusions of Lewis Binford who in his article Mortuary practices: their study and their potential (Binford 1971, pp. 6-29), stated that diversity of burials is, in fact, a reflection of social stratification. Researchers interested in the Roman period largely base their studies on the qualitative and quantitative diversity of funerary material, assuming that richly equipped graves belonged to rich people (social elites), and poorly equipped - to the poor (por. Kmieciński 1968; Wielowiejski 1976). Additionally, richly furnished burials are perceived from the perspective of the preset value of materials of which the items were made (gold, silver), despite the fact that in prehistoric communities they may not have been as significant as they are today (Gryzińska-Sawicka 2014, p. 51).

As an example may serve the works of a Danish archaeologist Lotte Hedeager. She assumed that comparative analyses of graves require standardization and quantification, as it is easy, in the course of the study of this type of relics of former human activities, to subjectively evaluate and determine burials containing the abundance of objects as "princely graves". To avoid diagnosing a priori, she invented a method called NAT (Number of Different Artifact Types ), used, e.g., for the study of burials from the Scandinavian area (Hedeager 1978, 1992). This method indicates the number of artifacts with different functions in the grave. For example, a single bone pin found in a grave gives one point in the NAT scale, however, three gold brooches will receive one point as well. As in this analysis the number of artifacts is not calculated, the "greatest" of them fail to define a grave as rich solely by their presence. A grave is defined as rich only if it contains many different types of items which contribute to the high value of NAT. Lotte Hedeager suggests that the indicated research method is particularly useful in the analysis of biritual burials, as it provides the possibility of comparing cremation to inhumation (Hedeager 1992, p. 104). It does not in- 
clude various items of the same type present in the grave but only the number of different types of artifacts. This is particularly important in the case of graves with cremated ashes, as it may be difficult, if not impossible, to determine whether a fragment of fibula is derived from one or more copies or whether there was more than one glass bead, etc. Therefore, in the NAT measurements one does not distinguish between a single piece of a ceramic vessel and several complete pots or between one fragment of a brooch and a few brooches. Although the researcher does not count the total number of objects in the tomb but only their categories, still she values the burials on the basis of the quantity and quality of these categories of artifacts. Yet, the problem in the application of the above method in the study of social structure is due to a very large number of robbed graves, as well as a small percentage of preserved children's graves in cemeteries of Wielbark population, which largely prevents the determination of NAT for multiple burials, and consequently blurs the entire picture. Analyses which took into account the number of artifacts in individual graves in Scandinavia were also conducted by Lars Jorgensen (Jorgensen 1988) who examined two Danish cemeteries. He calculated the index: value / status by dividing the total number of graves discovered in the cemetery by the number of artifacts of a particular type. For example, if in 400 graves a particular type of artifact appeared 4 times, the ratio was 400/4 which equals 100 (Ciesielska 2002, p. 62).

Considering Polish achievements, one has to mention the research by Jerzy Kmieciński on the social structure of population buried in the cemetery in Odry (Kmieciński 1968, pp. 40-41). Kmieciński came to conclusion that the degree of social stratification can be determined by setting the "value" of individual relics of the past. This value would depend on the amount of time necessary to produce the item, complexity of its production, as well as availability and value of the material. Frequency of occurrence of the object, any relationship with a specific type of grave, as well as aesthetic appeal was also taken into account in the course of analysis. On this basis, Jerzy Kmieciński has determined the value of individual objects using a scale which ranged from 0.5 to 7 points (Kmieciński 1968, p. 40). What is more, Kmieciński has distinguished five groups of wealth: 1. graves with no equipment; 2. graves poorly equipped (less than 5 points), 3 . graves with average equipment (up to 15 points); 4. richly equipped graves (up to 40 points); 5 very rich graves (total score above 40). This analysis assumed that prehistoric communities valued ores in the same manner in which we do it now, even though gold and silver might have had some significance not associated with their material value. The fact that the amount or the material of which the object was made may not have been as significant as we assume today, can be proved by the comments by John Schuster on materials obtained from the so-called "princely graves" in Lubieszewo (Schuster 2006, p. 165). Schuster pointed to the grave 1 from the Sandberg site where, among other items, A VI silver brooches, 71 were discovered. These brooches, as noted by John Schuster, fail to constitute masterpieces of goldsmith craftsmanship, despite being made 
entirely of silver and allocated to a stately burial. The craftsman did not master the art of casting, moreover, he left them unfinished: on the surface of the brooches there are some visible casting defects and partially sharp seams. None of the brooches has a finished sheath, which indicates that they could not have been used to fasten the garment. Their function was rather representational or symbolic (Schuster 2006, p. 166). This stands in opposition to the assumptions of processual studies which assume that burials reflect social reality. In 1982 Ian Hodder opposed the conviction indicating that funeral is a rite of passage strictly dependent on the beliefs and ideologies. All this, as emphasized in the works of neo-marxist archaeologists, can realistically blur the existing social relations through the realm of the symbolic - this possibility was not taken into account by processual archeologists (Ciesielska 2012, p. 64).

Methods of analysis of social structure based on quantitative and qualitative differentiation of material are also used in order to determine whether valuables are distributed "evenly" or concentrated in only a few graves within the cemetery; if graves containing elements of armor are richer than others; if the distribution of wealth is even for men and women, or if one can point the differences in the equipment of both sexes, then, in the equipment of the same sex, depending on age; if there are any geographic and / or chronological differences.

Statistical methods in such cases are used for testing strength of the correlation between variables (i.a. Czarnecka 1990), such as:

- sex (checking if there is any correlation between: sex of the deceased and the amount of equipment placed in the grave; sex and type of the grave; sex and the material of which objects were made; sex of the deceased and the type of objects placed in the grave),

- age (correlation between age of the deceased and type of grave, age and the amount of equipment placed in the grave, age and the material of which objects were made),

- chronology of the grave (correlation between chronology and type of grave, chronology and the amount of equipment placed in the grave; chronology and the material of which the object placed in the grave was made, chronology and type of the object),

- type of grave (correlation between type of grave and the amount of equipment placed in the grave; type of grave and type of objects placed in the grave, type of grave and the material of which objects were made).

With this kind of analysis, a researcher, however, faces many difficulties when attempting to correlate archaeological data with information concerning the age or sex of people buried in the analyzed cemeteries. First of all, one may indicate a problem with the number of anthropological determinations for the cemeteries of the Wielbark culture. It is associated with a very poor (in most necropolises of that cultural unit) state of preservation of the bones, hindering the work of physical an- 
thropologists. The funeral rite itself, in this case biritualism, constitutes a great obstacle itself, seriously preventing sex designation of individuals, as most of the features on bones were damaged (deformed, fragmented and contracted) during cremation (Koczorowski, Kajmowicz and Florkowski 2013, p. 83). Anthropologists suggest that determination of age becomes less accurate for individuals over 30 years old - hence a very frequent appearance of category "adult" replacing more accurate maturus or senilis. Such designations are blurring real divisions depending on age - if, in fact, there ever were any. In addition, one often forgets that the age at the time of death diagnosed on the basis of bone material is not based on chronology, calendar or any register, but it is biological / developmental age (Budnik 2014, p. 29). People of the same age can greatly vary in terms of biological development. A great difficulty constitutes the fact that recent studies still determine the age on the basis of the degree of cranial suture obliteration, although a few years ago a conducted research revealed that the coalescence of the sutures is not due to the natural aging process and cannot be used in the process of determining age (Budnik 2014, p. 31; Herskovitz et al. 1997). For example, people with fully open or slightly rigid seams were between 19 and 90 years old, and the age of those with skulls almost completely or completely rigid ranged from 28 to 89 years old (Dayal 2009, tab. 5.12, p. 141).

Problems with determining age and sex of the deceased (especially the latter) are visible in the largest Wielbark cemeteries. For example, at the cemetery in Pruszcz Gdański (Pietrzak 1997) site 10 among 161 graves from the Roman period it was possible to determine the age of the deceased in 101 cases, whereas sex was determined in 89. The data are similar for Kowalewko (Skorupka 2001): of 495 graves age of the deceased was identified in 315 cases, while sex only in 119. In Weklice (Teul 2011, pp. 151-172) of 492 graves age was established in the case of 161 deceased and sex in 122. Difficulty in determining sex of the deceased is also highlighted by the results themselves - if the documentation includes determination of sex, it is often accompanied by a question mark, indicating the application of archeological material and the assumption that Wielbark graves equipped with numerous brooches and ornaments belonged to women, while the more modest ones to men. For smaller necropolises statistics are even more negative: for example, in Ulkowy, of 125 burials age of the deceased was determined in 33 cases, and sex in 19 (Rożnowski 2005, pp. 81-97); in Szczypkowice of 31 burials age was identified in 13 cases while sex in only 3 (Machajewski, 2002); in Gostkowo of 53 burials age was established in 5 cases, while sex in 3 (Kurpiński 2008, pp. 70-71). In Zakrzewska Osada of 137 burials age was determined in 100 cases, sex only in 43 (Koczorowski, Kajmowicz and Florkowski 2013, p. 85). Such ratio of burials with specific anthropological features to their general number in a cemetery significantly impedes the study of social structure, concerning the age and sex of the deceased. 
The above problem could be solved by increasing the number of studies (unfortunately very expensive) of fossil DNA and microelements. Analysis of fossil DNA is, in fact, only possible with materials from those cemeteries which are presently studied, as long as suitable sampling is provided. DNA degradation starts immediately at the time of death and in case of unfavorable conditions it may proceed rapidly. Fragmentation and modification of fossil DNA can be also accelerated by environmental factors, climate, temperature, bacteria, fungi, insects, as well as type of soil, its chemistry and pH, etc. (Budnik 2014, pp. 28). Remains exposed in the course of archaeological study are prone to destruction in the process of erosion or through UV radiation - in such conditions DNA degradation processes rapidly (Bąbol-Pokora, Jacewicz and Bernet 2014, p. 74). Therefore, analyzing materials stored in museum warehouses for several years will probably bring no results. As the ideal conditions protecting the DNA from damage is lack of moisture and low temperature, bones for DNA analysis should be frozen immediately after they were excavated and documented and stored at a temperature of at least $-20^{\circ} \mathrm{C}$ until they can become a subject of analysis (Bąbol-Pokora, Jacewicz and Bernet 2014, p. 75). However, if the samples are properly collected, it is possible to obtain a significant percentage of sex determination, which could supplement the standard anthropological research. DNA testing may also prove to be useful for direct attempts to obtain information about the ancestral structure and kinship of individuals buried in prehistoric cemeteries. It could be also used to confirm or deny the existence of ancestral sectors within a cemetery.

The social structure can be also discussed from the perspective of data obtained through the study of stable isotopes of nitrogen, carbon and oxygen which indicate the type and quality of diet. These studies are based on the fact that wide spectrum of human nutrition includes many species of flora and fauna, and that diet is not identical for the entire population. It is determined by the area of residence, climate, flora, season, sex and age. In order to determine the type of food consumed, it is crucial to study isotopes of nitrogen and carbon which indicate, for example, whether the diet consisted only of fish or both aquatic and terrestrial organisms (Szostek and Stepańczak 2009, p. 129). Isotopes of nitrogen and oxygen may also indicate the moment of breastfeeding withdrawal of a child and the introduction of other foods, as much as contribute to determining the origin of an individual (Szostek and Stepańczak 2009, p. 129). As it is with all methods, the analysis of stable isotopes also has its limitations, as it was demonstrated by the attempts to determine the diet of the population of Wielbark culture made in 2013 by Laurie Reitsem and Tomasz Kozłowski. At the very beginning the authors pointed to the significant narrowing of research opportunities through the presence of a large number of cremation burials in the cemeteries of a discussed culture (Reitsema and Kozłowski 2013, p. 2). For their study they used materials from the cemetery in Rogowo (Kuyavian- 
Pomeranian Voivodeship) (Chudziak 2000), with extremely well-preserved skeletal material. While reconstructing the diet, they took into account the correlation between diet and sex, age, presence or absence of funerary equipment (Reitsema and Kozłowski 2013, p. 3). The results obtained show that the women's diet contained more grain and less animal proteins (meat or dairy) than men's diet. The researchers suggested, however, that these results do not necessarily indicate the differences in access to particular types of food depending on sex. They may be the result of a different origin of the population (Reitsema and Kozłowski 2013, p. 16). This is due to the fact that plants grown in warm climates have higher percentage of isotope ${ }^{13} \mathrm{C}$ than the same plants grown in cooler environment - in this case women from Rogowo would be outsiders. This ambiguity of results largely hinders the possibilities of this method when attempting to study social differences arising, for example, from diet and sex. On the other hand, such analyses, including studies of strontium, could bring forth some interesting results concerning the origin of population buried in the cemeteries and the system of marriage matching during the period of Roman influence in Poland. Samples from Rogowo suggested also that the differences in the number of stable isotopes in the necropolis were not due to the diversification of funerary objects in women's graves, (in this case, the Wielbark culture may be seen as relatively egalitarian), in which biological variables (such as sex) play a greater role in the structure of diet than in the social structure (Reitsema and Kozłowski 2013, p. 16).

The social structure is also explored through the study of divisions arising from, for example, people's work and sex. Frequently in such cases one includes various assumptions, springing from employed methodology, as "facts revealed". Older works of this type are dominated by the Marxist approach emphasizing the importance of people with rich furnishings, especially men - warriors buried with their weapons. Jerzy Wielowiejski for example, describing the funeral rites of Przeworsk culture, highlighted the wealth of men's graves:

[...] when comparing male and female graves the difference between rich male and generally poorer female graves is indeed striking. It was probably a result of different habits related to equipping deceased men and women, and, therefore, men's graves containing weapons are richer than corresponding female graves. It seems, however, that although the reflection of differences in wealth has been partially disrupted, the dominant position of men in society is still displayed (Wielowiejski 1976, p. 191).

The phenomenon of weapons present in the male graves of the Przeworsk culture and rich, by modern standards, female burials in Wielbark was recently a subject of studies by Tomasz Galak who attempted to explain it through the use of a simplified method of structural description (after C. Lévi-Strauss) and the indication of binary oppositions present in the funeral rites of the Wielbark and Przeworsk 
cultures (Gralak 2012, p. 390). Galak distinguished eleven opposition on the basis of 0: 1 system, ie. Phenomenon - no phenomenon or phenomenon - the opposite of phenomenon. Analysis conducted on the basis of archaeological findings and information obtained from ancient written sources allowed for the indication of difference in socio-political "systems", power, and the role of men or women as information carriers, etc.

Jacek Woźny also pointed to the problem generated by various attempts to assign specific artifacts or tools to particular sex or social function. He analyzed the so-called burials of women-potters and men-blacksmiths which contained polishing stones and pebble tools (Woźny 2011, pp. 43). Stones, placed in the graves, bearing traces of refinement, are usually literally equated either with tools used for vascular pottery, skinning, or to refine the surface of a metal object in a cold forming process. Jacek Woźny wrote:

[...] theory, accepted in archeology, of social division of labor in prehistoric times argues that the process of forming metal objects remained under the supervision of men in the beginnings of professional specialization. [...] Simple selection criteria lead to clear research results allowing to distinguish women-potters' graves with pebble polishing stones from burials of men-metallurgists and blacksmiths equipped, among others, with grooved stones ("Rillensteine" or "Kannelirensteine"), and later with whetstones made of sandstone (Woźny 2011, pp. 45-46).

This approach (especially emphasizing the role of men in the creative process, as well as in the development of culture) is also represented by Jerzy Wielowiejski, who pointed to the social differences resulting from labor. He wrote:

In the light of ethnographic relics manual clay modeling has always been a home occupation of women [...] It must, therefore, be assumed that also pottery which used the technique of manual modeling was in Poland in late antiquity in the hands of women [...] These circumstances resulted in the fact that, in technical terms, after reaching its peak point in the last century BC pottery failed to develop any further. In the third century the reappearance of pottery using a wheel was already associated with the activity of men specialized in their profession (Wielowiejski 1976, p. 93).

Views binding certain categories of activities with particular sex are usually observations transferred from modern times to prehistory. It is supposed to happen on the basis of a specific universal division of labor and activity areas determined by sex (Hodder 1995, p. 203). However, the division of labor, although related to biological determinants of both sexes, is not determined, which is indicated also in ethnographic research (Renfew and Bahn 2002, p. 206). Ethno-linguistic works are also crucial in this aspect, dealing with the study of the division of activities and searching for the roots of words describing a person and the act of manufacturing. 
However, there is a problem here, as according to some linguists, the original language had no female grammatical gender. This was true, among others, for Anatolian language - one of the oldest Indo-European languages in which female grammatical gender is absent. Only for special emphasize of the "femininity" suffix -sor was sometimes added (Siewiaryn 2011, p. 12). It appears, thus, that these commonly used simple selection criteria discussed by Jacek Woźny, omit many aspects, including the fact that burial is largely a result of a ritual and ideas about the afterlife. In this case, stone tools found in burial contexts, rather than constituting references to the temporal life, may have eschatological significance, be a part of funeral rituals, assist resurrection of the dead or have some apotropaic functions (Woźny 2011, p. 47).

As noted by Mads Ravn (Ravn 2003, pp. 12-22), data obtained from cemeteries will always be incomplete and archaeological data constitute only a part of the information concerning the events that took place and which did not necessarily leave a mark in the excavation material. These events were associated with worldview, ideology, beliefs. Burial, as a matter of fact, is an intentional action, which contains items specially selected for this purpose by the family, relatives, neighbors, and also perhaps according to the last wish of the deceased. There is no way to analyze it well without taking into consideration emotions associated with dying, death and memory (Minta-Tworzowska 2009, p. 148). The form of burials may be also affected by various factors such as, for example, fashion related to the way of expressing aspirations of family members. Aubrey Cannon called this phenomenon "competitive display" (Cannon 1989, p. 437). As noted by Adriana Ciesielska, it is also important to realize that a researcher chooses a statistical method which will be used to examine burial data, as much as he or she determines the elements or characteristics of burials which are to be taken into account in the analysis of the social aspect of a cemetery (Ciesielska 2012, p. 23). This shows how subjective studies of this type are and how selective results they may bring.

It turns out, therefore, that when asking about the social structure and using methods in order to obtain answers to it, what we really ask about is the attitude of the living towards death and towards the dead themselves, about the expression of the last will of the deceased, aspirations of the family, etc. Hence, there is a need to reflect on the issue: how social and personal identity (eg, related to sex or age) was created and manifested through the use of specific items and in what way the attitude towards afterlife was determined. These are not the dead who bury themselves - it is the society (Meskell 1994, p. 40) in which they lived: neighbors, friends and family (most often in mourning, fear or other emotions which accompany death). Burial, thus, becomes a certain theater of social interactions (Ciesielska 2007, p. 195), which, through its simultaneous connection to the realm of the living and its reference to eschatology, may often stand in opposition to life. 


\section{REFERENCES}

Bąbol-Pokora K., Jacewicz R. and Berent J.

2014 Współczesna genetyka w służbie archeologii. In: W. Dzieduszycki and J. Wrzesiński (eds.), Królowie i biskupi, rycerze i chłopi-identyfikacja zmartych. Funeralia Lednickie (vol. 16, pp. 73-80). Poznań: Stowarzyszenie Naukowe Archeologów Polskich. Oddział: Biblioteka Telgte Wydawnictwo.

Binford L.

1972 Mortuary practices: their study and their potential. In: J.A. Brown (ed.), Approaches to the Social Dimensions of Mortuary Practices (vol. 25, pp. 6-29). New York: Memoris of the Society for American Archaeology.

Budnik A.

2014 Identyfikacja ludzi na podstawie materiałów szkieletowych - pewność czy prawdopodobieństwo? O możliwościach i ograniczeniach badań. In: W. Dzieduszycki and J. Wrzesiński (eds.), Królowie i biskupi, rycerze i chtopi - identyfikacja zmarlych. Funeralia Lednickie (vol. 16, pp. 25-43). Poznań: Stowarzyszenie Naukowe Archeologów Polskich. Oddział : Biblioteka Telgte Wydawnictwo.

Chudziak W.

2000 Archeologia na bydgosko-toruńskim odcinku autostrady A1. Z Otchłani Wieków, 55 (Archeologia na dużch inwestycjach w Polsce), pp. 28-32.

Ciesielska A.

2002 Elementy teorii spotecznej $w$ archeologii: koncepcje grup, instytucji i struktur spotecznych. Poznań-Kalisz: Wydawnictwo WPA - UAM.

Ciesielska A.

2007 Memento mori. Żyjący wobec śmierci i zmarłych na przestrzeni dziejów. In: W. Dzieduszycki and J. Wrzesiński (eds.), Środowisko pośmiertne człowieka. Funeralia Lednickie (vol. 9, pp. 193-196). Poznań: Stowarzyszenie Naukowe Archeologów Polskich.

Ciesielska A.

2012 Przemiany kulturowe na obszarze między Odra a Wista na przelomie starożytności i średniowiecza. Studium metodologiczne. Poznań: Wydawnictwo Naukowe UAM.

Czarnecka K.

1990 Struktura społeczna ludności kultury przeworskiej. Warszawa: Państwowe Wydawnictwo Rolnicze i Leśne.

Dayal M.

2009 Polymorphism of cranial suture obliteration in adult crania. [Doctor of Philosophy Dissertation, University of Adelaide, School of Medical Science].

Godłowski K.

$1960 \quad$ Studia nad stosunkami społecznymi $w$ okresach późnolateńskim i rzymskim $w$ dorzeczu Odry $i$ Wisły. Warszawa-Wrocław: Zakład Narodowy im. Ossolińskich - Wydawnictwo.

Gralak T.

2012 Przyczyny i formy zróżnicowania kultur przeworskiej i wielbarskiej. In: B. Gediga, A. Grossman and W. Piotrowski (eds.), Rytm przemian kulturowych w pradziejach $i$ średniowieczu (pp. 389-410). Biskupin-Wrocław: Muzeum Archeologiczne, Polska Akademia Nauk. Oddział Wrocław.

Gryzińska-Sawicka N.

2014 Obraz struktury społecznej ludności kultury wielbarskiej w świetle źródeł archeologicznych i danych archeologicznych. In: W. Dzieduszycki and J. Wrzesiński (eds.), Królowie 
i biskupi, rycerze i chlopi - identyfikacja zmarlych. Funeralia Lednickie (vol. 16, pp. 51-61). Poznań: Stowarzyszenie Naukowe Archeologów Polskich. Oddział: Biblioteka Telgte Wydawnictwo.

Hedeager L.

1978 Process towards state formation in Early Iron Age Denmark. In: New Directions in Scandinavian Archaeology (pp. 217-223). Copenhagen: The National Museum of Denmark.

Hedeager L.

1992 Iron - Age Societies. From Tribe to State in Northern Europe 500 BC to AD 700. Oxford: Blackwell.

Herskovitz I., Latimer B., Dutuor O., Jellema L.M., Wishbaratz S. and Rothscgild C.

1997 Why do the fail in aging the skull from the sagittal suture? American Journal of Physical Anthropology, 103, pp. 393-399.

Hodder I. 1982

Hodder I.

1995

Jørgensen L.

1988 Family burials practices and inheritance systems. The development of an Iron Age socie-

Kietlińska A. ty from $50 \mathrm{BC}$ to AD 1000 on Bornholm, Denmark. Acta Archaeologica, 58, pp. 17-53.

1960 Problem tzw. grobów książęcych we wczesnym okresie rzymskim. Wiadomości Archeologiczne, 26, pp. 98-115.

Kietlińska A.

1963 Struktura społeczna ludności kultury przeworskiej. Materiały Starożytne, 9, pp. 7-98.

Kmieciński J.

1968 Odry. Cmentarzysko kurhanowe $w$ okresu rzymskiego $w$ powiecie chojnickim. Łódź:

Łódzkie Towarzystwo Naukowe, Zakład Narodowy im. Ossolińskich - Wydawnictwo.

Koczorowski T., Kajmowicz B. and Florkowski A.

2013 Analiza antropologiczna materiałów kostnych. In: J. Szałkowska-Łoś and J. Łoś (eds.), Zakrzewska Osada. Cmentarzyska kultury pomorskiej i wielbarskiej na Pojezierzu Krajeńskim (Ocalone dziedzictwo archeologiczne, vol. 2, pp. 81-103). Bydgoszcz-Pękowice: Muzeum Okręgowe im. Leona Wyczółkowskiego, Wydawnictwo i Pracownia Archeologiczna Profil-Archeo Magdalena Dzięgielewska.

Kurpiński A.

2008 Cmentarzysko kultury wielbarskiej w Gostkowie. In: C. von Carnap-Bornheim, J. Ilkjær and A. Kokowski (eds.), Supplementa Monumenta Studia Gothica (z. 1), Lublin: Instytut Archeologii UMCS.

Machajewski H.

2002 Cmentarzysko ludności kultury wielbarskiej w Szczypkowicach, woj. pomorskie. In: Varia Barbarica. Monumentna Archaeologica Barbarica, Series Gemina (vol. 1, pp. 311-332). Warszawa-Lublin: Fundacja Przyjaciół Instytutu Archeologii Uniwersytetu Warszawskiego, Instytut archeologii UMCS w Lublinie, Państwowe Muzeum Archeologiczne w Warszawie.

Meskell L.

1994 Dying Young: the experience of death at Deir El Medina. Archaeological Review from Cambridge, 13(2), pp. 35-45. 
Minta-Tworzowska D.

2009 Archeologia i jej źródła wobec problematyki śmierci. In: W. Dzieduszycki and J. Wrzesiński (eds.), Metody. Źródła. Dokumentacja. Funeralia Lednickie (vol. 11, pp. 147-152). Poznań: Stowarzyszenie Naukowe Archeologów Polskich.

Pietrzak M.

1997 Pruszcz Gdański, Fundstelle 10. Ein Gräberfeld der Oksywie- und Wielbark Kultur in Ostpommern. Monumenta Archaeologica Barbarica (vol. IV), Kraków: Secesja.

Ravn M.

2003 Death Ritual and Germanic Social Structure (c. A.D. 200-600) (British Archaeological

Renfew C. and Bahn P. Reports International Series 1164). Oxford: Archaeopress.

2002 Archeologia. Teorie, metody, praktyka. Warszawa: Prószyński i S-ka.

Reitsema L.J. and Kozłowski T.

2013 Diet and society in Poland before the state: stable isotope evidence from a Wielbark

Rożnowski F. population $\left(2^{\text {nd }}\right.$ c. AD). Antropological Review, 76(1), pp. 1-22.

2005 Cmentarzysko w Ulkowach, gm. Pszczółki - analiza antropologiczna materiałów kostnych. In: M. Tuszyńska (ed.), Ulkowy. Cmentarzysko kultury wielbarskiej na Pomorzu Gdańskim (badania na trasie autostrady Al Gdańsk-Toruń) (pp. 81-97). Gdańsk: Muzeum Archeologiczne w Gdańsku.

Schuster J.

2006 Lubieszewo (Lübsow) - prawie 100 lat po odkryciu pierwszego grobu książęcego na Pomorzu Zachodnim. In: W. Nowakowski (ed.), Goci i ich sąsiedzi na Pomorzu. Materialy z konferencji ,, Goci na Pomorzu Środkowym”, Koszalin 28-29 października 2005 (pp. 161-172). Koszalin-Wrocław: Muzeum w Koszalinie, Wydawnictwo Zet.

Siewiaryn M.

2011 Z pewnością jak dawniej, utarty tradycją, istniał podział zajęć według płci... - kilka uwag o miejscu źródeł archeologicznych w konstruowaniu obrazu struktury społecznej w pradziejach. In: Obraz struktury społecznej w świetle źródel archeologicznych w pradziejach i średniowieczu (pp. 7-16). Rzeszów: Fundacja Rzeszowskiego Ośrodka Archeologicznego; Instytut Archeologii Uniwersytetu Rzeszowskiego.

Skorupka T.

$2001 \quad$ Kowalewko 12. Cmentarzysko birytualne ludności kultury wielbarskiej (od połowy I w. n.e. do początku III w. n.e.). Archeologiczne badania ratownicze wzdtuż trasy gazociagu tranzytowego (Wielkopolska, cz. 3). Poznań: Wydawnictwo Poznańskie.

Szostek K. and Stepańczak B.

2009 Zastosowanie analizy stabilnych izotopów w antropologii - wstępne wyniki badań. In: W. Dzieduszycki and J. Wrzesiński (eds.), Metody. Źródła. Dokumentacja. Funeralia Lednickie (vol. 11, pp. 125-140). Poznań: Stowarzyszenie Naukowe Archeologów Polskich.

Teul I.

2011 Results of osteology analysis of evidence from birytual cemetery of Wielbark Culture at Weklice, site 7, comm. Elbląg, voiv. Warmińsko-Mazurskie. In: M. Natuniewicz-Sekuła and J. Okulicz-Kozaryn (eds.), Weklice. A cemetery of the Wielbark Culture on the Eastern Margin of Vistula Delta (Excavations 1984-2004) (Monumenta Archaeologica Barbarica, vol. XVII). Warszawa: Fundacja Monumenta Archaeologica Barbarica, Instytut Archeologii i Etnologii PAN. 
Wielowiejski J.

1976 Życie codzienne na ziemiach polskich w okresie wpływów rzymskich (I-VI w.). Warszawa: Państwowy Instytut Wydawniczy.

Woźny J.

2011 Garncarki i kowale, czyli eschatologiczna symbolika wybranych narzędzi kamiennych w pradziejowych obrzędach pogrzebowych. In: W. Dzieduszycki and J. Wrzesiński (eds.), Kim jesteś człowieku? Funeralia Lednickie (vol. 13, pp. 43-50). Poznań: Stowarzyszenie Naukowe Archeologów Polskich.

\section{MOŻLIWOŚCI I OGRANICZENIA METOD BADANIA STRUKTURY SPOŁECZNEJ Z OKRESU WPŁYWÓW RZYMSKICH NA ZIEMIACH POLSKICH}

\section{Streszczenie}

Struktura społeczeństw pradziejowych stanowi interesujący, ale i trudny problem badawczy. W odniesieniu do okresu przedrzymskiego i wpływów rzymskich w Polsce można wymienić prace Kazimierza Godłowskiego (1960), Aliny Kietlińskiej (1960, 1963) oraz Krystyny Czarneckiej z 1990 r. - dotyczą one przede wszystkim kultury przeworskiej. O strukturze społecznej często mówi się w archeologii za pomocą powtarzanych schematów, nierzadko aplikowanych do różnych okresów pradziejów, najczęściej kładących nacisk na różnice klasowe, na jakie ma „wskazywać” wyposażenie grobów. W ten sposób omawiane zagadnienie analizowane jest najczęściej pod kątem wyposażenia osobników pochowanych na cmentarzyskach - na podstawie jakościowego i ilościowego zróżnicowania materiału grobowego. Zakłada się zatem, że groby bogato wyposażone należały do osób bogatych (elit społecznych), wyposażone zaś ubogo - odpowiednio - do osób biednych (m.in. prace archeologów skandynawskich: Lotte Hedeager, Larsa Jorgensena, i polskich: Jerzego Kmiecińskiego). Brana jest także pod uwagę obecna wartość materiałów, z jakich wykonano przedmioty (złoto, srebro), mimo że mogły one nie mieć takiego znaczenia jak dziś.

Dużym problemem w badaniach nad strukturą społeczną okazuje się źle zachowany materiał kostny, który często uniemożliwia antropologom określenie płci i wieku zmarłych. Trudności sprawia nie tylko sam rodzaj obrządku pogrzebowego, czyli birytualizm, lecz także metody. Antropolodzy wskazują, że ustalenia wieku stają się mniej precyzyjne dla osobników po 30. roku życia, co może zacierać podziały społeczne w zależności od wieku - o ile takowe istniały. Ponadto często zapomina się, że zdiagnozowany na podstawie materiału kostnego wiek w chwili śmierci nie jest wiekiem chronologicznym, kalendarzowym czy metrykalnym, lecz biologicznym/rozwojowym. Dodatkowym problemem są także starsze analizy, które wykorzystywały do określenia wieku stopień obliteracji szwów czaszkowych, obecnie uznany za metodę błędną.

Rozwiązaniem mogłyby okazać się badania kopalnego DNA, dzięki którym możliwa byłaby odpowiedź na pytania dotyczące pokrewieństwa oraz ewentualnego istnienia sektorów rodzinnych na cmentarzyskach. Również badania stabilnych izotopów tlenu, azotu i węgla, choć niepozbawione ograniczeń, mogą wesprzeć archeologię w odpowiedzi na stawiane przez nią pytania o to, czy dieta mogła mieć związek z pozycją społeczną (czy zależała od płci, wieku, od bogactwa itd.). 
Wszystkie one wymagają jednak odpowiedniego postępowania z materiałem podczas eksploracji, tak by jak najmniej informacji uległo zdegradowaniu.

Wreszcie w studiach nad strukturą społeczną można wykorzystywać także badania nad pracą i jej podziałami ze względu na płeć. W starszych opracowaniach tego typu, dotyczących okresu rzymskiego, dominuje podejście marksistowskie uwypuklające znaczenie osób z bogatym wyposażeniem, szczególnie zaś mężczyzn - wojowników, których pochowano z bronią. Poglądy wiążące poszczególne kategorie czynności z konkretną płcią są zazwyczaj przeniesieniem obserwacji z czasów współczesnych do pradziejów. Ma to się dziać na podstawie swoistego rodzaju uniwersalnego podziału pracy i obszarów aktywności wyznaczonych przez płeć. Jednakże podział pracy, choć związany z biologicznymi uwarunkowaniami obu płci, nie jest przecież zdeterminowany. Na problem, jaki generują próby przyporządkowania konkretnych artefaktów czy narzędzi do konkretnej płci bądź funkcji społecznej, wskazywał ostatnio Jacek Woźny, analizując tzw. pochówki garncarek i kowali. Badacz ten uważa, że wiele narzędzi mogło mieć odniesienia nie tyle do życia doczesnego, ile przyszłego, wspomagać rezurekcję zmarłych czy pełnić funkcje apotropeiczne.

W studiach nad strukturą społeczną na podstawie materiałów z nekropolii pradziejowych istotne jest uświadomienie sobie, iż dane z cmentarzysk zawsze będą niekompletne, a dane archeologiczne to tylko część informacji o dawnych wydarzeniach, a niekoniecznie pozostawiły ślad w materiale wykopaliskowym. Pochówek był i jest działaniem intencjonalnym, na który wpływ mają: aspiracje członków rodziny zmarłego, żal, emocje związane ze śmiercią, a nawet panująca „moda”. Stąd konieczność zastanowienia się nad tym, w jaki sposób społeczna i indywidualna tożsamość (na przykład związana z płcią czy wiekiem) była kreowana i manifestowana za pomocą przedmiotów oraz w jaki sposób określano stosunek do przyszłego życia w zaświatach. Pytając zatem o strukturę społeczną i stosując metody mające pomóc w uzyskaniu wiedzy na jej temat, w rzeczywistości pytamy o stosunek żyjących do zmarłego i do śmierci oraz o wyobrażenie przyszłego życia. 